hypotensive agents said that they felt better with clonidine than with the other drugs. There was no clinical, haematological, or biochemical evidence of serious toxicity, even though several patients received dosage higher than other investigators have recorded. Mental changes, however, appear to be a hazard of clonidine treatment ( $\mathrm{Ng}$ et al., 1967), as might be expected from its central depressant effect. Those with a previous history of depressive illness and those with advanced cerebrovascular disease seem to be especially at risk.

Undoubtedly drug tolerance occurs, especially in the early weeks of therapy. Blood pressure tended to escape from control shortly after the patient left hospital, but higher dosage usually restored satisfactory levels, and thereafter increases of dose were infrequent. It has been suggested (Davidov et al., 1967) that the apparent tolerance is due to sodium retention and can be overcome by adding an oral diuretic. This has not been evident in our limited experience, but the point probably deserves further study.

We are indebted to Dr. Julian H. Shelley, Medical Director of Boehringer Ingelheim Ltd., who made available generous supplies of clonidine for this study.
REFERENCES

Barnett, A. J., and Cantor, S. (1968). Medical fournal of Australia, 1, 87. Bock, K. D., Heimsoth, V., Merguet, P., and Schonermark, J. (1966). Deutsche medizinische Wochenschrift, 91, 1761.

Davidov, M., Kakaviatos, N., and Finnerty, F. A. (1967). Clinical Pharmacology and Therapeutics, 8, 810 .

Frank, K., and von Loewenich-Lagois, K. (1966). Deutsche medizinische Wochenschrift, 91, 1680.

Grabner, G., Michalek, P., Pokorny, D., and Vormittag, E. (1966). Arzneimittel-Forschung, 16, 1174.

Graubner, W., and Wolf, M. (1966). Arzneimittel-Forschung, 16, 1055.

Iisalo, E., and Laurila, S. (1967). Current Therapeutic Research, 9, 358.

Kochsiek, K., and Fritsche, H. (1966). Arzneimittel-Forschung, 16, 1154.

Lancet, 1969, 2, 529.

Lieb, W., and Ridders, K. (1966). Arzneimittel-Forschung, 16, 1610.

Michel, D., Zimmermann, W., Nassehi, A., and Seraphim, P. (1966). Deutsche medizinische Wochenschrift, 91, 1540.

Muir, A. L., Burton, J. L., and Lawrie, D. M. (1969). Lancet, 2, 181

$\mathrm{Ng}$, J., et al. (1967). New Zealand Medical fournal, 66, 864.

Onesti, G., Schwartz, A. B., Kim, K. E., Swartz, C., and Brest, A. N. (1969). Circulation, 39, 219.

Raftos, J. (1969). Medical fournal of Australia, 2, 684.

Smet, G., Hoobler, S. W., Sanbar, S., and Julius, S. (1969). American Heart fournal, 77, 473 .

Zaimis, E., and Hanington, E. (1969). Lancet, 2, 298.

\title{
Xylene Poisoning: A Report on One Fatal Case and Two Cases of Recovery after Prolonged Unconsciousness
}

\author{
R. MORLEY, ${ }^{*}$ M.B., CH.B., D.I.H. ; D. W. ECCLESTON, $†$ M.B., B.S., M.R.C.P. ; C. P. DOUGLAS $\ddagger$ \\ W. E. J. GREVILLE, $\$ M.A. ; D. J. SCOTT,\| M.B., B.S. ; J. ANDERSON, M.B., B.S., M.R.C.P.
}

\begin{abstract}
Summary: Three cases of xylene poisoning occurred $\checkmark$ after prolonged inhalation of paint fumes. Analysis showed that xylene comprised more than $90 \%$ of the solvent in the paint, the total solvent comprising $34 \%$ of the paint by weight. One patient was dead on admission, while the other two recovered after at least 15 hours' loss of consciousness. Both patients had transient liver cell damage, and one temporary impairment of renal function.
\end{abstract}

\section{Introduction}

Xylene is irritant to the skin and mucous membranes (Johnstone and Miller, 1960; Browning, 1965) and prolonged exposure causes considerable gastrointestinal upset. The principal acute effect of xylene is narcotic (Browning, 1965) though complete unconsciousness is rare and no fatal cases have been reported following exposure to the pure substance or to mixtures containing it.

\section{Case Reports}

Three men aged 54, 52, and 24 were employed by a firm of shipbuilders and were instructed to paint a double-bottomed tank in the engine room of a ship. The paint was to be applied by brush. The space was in the form of a coffer dam surrounding two lubricating oil-storage tanks and was about $17 \mathrm{ft}$. 2 in. wide $(5.33 \mathrm{~m}),. 17 \mathrm{ft} .6$ in. long $(5.43 \mathrm{~m}$.) and $4 \mathrm{ft} .8 \mathrm{in}$. $(1.42 \mathrm{~m}$.) high. It was made up of small cells and access was via two manholes in

* H.M. Medical Inspector of Factories, Northern Division.

† Medical Registrar, Royal Victoria Infirmary, Newcastle upon Tyne. ¥Chief Safety Officer, Swan Hunter Group Ltd., late H.M. Inspector of Factories.

$\checkmark$ H.M. District Inspector of Factories, Newcastle upon Tyne.

|| Demonstrator in Pathology, University of Newcastle upon Tyne.

I Senior Lecturer in Medicine and Honorary Consultant Physician, University of Newcastle upon Tyne and the Royal Victoria Infirmary, Newcastle upon Tyne. the end of the tank. Each manhole measured about $1 \mathrm{ft} .8$ in. by $1 \mathrm{ft} .3$ in. $(51$ by $38 \mathrm{~cm}$.).

Work apparently began at about 10.30 a.m. and though the men were due to finish at 4.30 p.m. it was not until later in the evening that a search for them was made. This continued until 5 a.m. next day, when the three men were found apparently unconscious. Though there was a strong smell of solvent fumes, the rescuers were able to work without breathing apparatus, and at about 6 a.m. the men were taken to the Royal Victoria Infirmary, Newcastle upon Tyne.

\section{Case 1}

This man was dead on arrival. Necropsy, carried out 12 hours after death, showed a well-nourished man with pronounced cyanosis of the head and extremities. The heart weighed $400 \mathrm{~g}$. and showed slight left ventricular hypertrophy. Both lungs were heavy and plum-coloured; the right weighed $900 \mathrm{~g}$. and the left $850 \mathrm{~g}$. The cut surfaces were deeply congested and copious amounts of fluid exuded from them. The liver was congested but otherwise appeared macroscopically normal.

Histological examination of the lungs showed severe congestion with focal intra-alveolar haemorrhage and acute pulmonary oedema with pink-staining amorphous material within the alveolar lumina. The liver showed congestion, with swelling and vacuolation of many cells, confined mainly to centrilobular areas. The brain showed microscopical petechial haemorrhages in both grey and white matter and haemorrhages in Virchow-Robin spaces. There was evidence of anoxic neuronal damage with swelling and loss of Nissl substance.

\section{Case 2}

On admission to hospital this man was unconscious and showed only slight response to painful stimuli. His temperature was $90^{\circ} \mathrm{F}$ $\left(32.2^{\circ} \mathrm{C}\right.$.) and he was shivering intermittently. His face was flushed, there was peripheral cyanosis, and his expired air smelled 
strongly of solvent fumes. The pulse was regular at 90 per minute and the blood pressure was 100/80. Heart sounds were normal. Frequent medium-grade moist sounds were audible over all lung fields. Investigations on admission are shown in the Table.

Emergency treatment consisted of tracheal aspiration and oxygen; because of the likelihood of inhalation of vomit intramuscular ampicillin was given. After five hours he was conscious but confused. He was amnesic for events which occurred during the 24 hours before his collapse and this amnesia persisted. His confusion disappeared over the next two to three days. There was evidence of considerable impairment of renal function and his blood urea rose from $59 \mathrm{mg} . / 100 \mathrm{ml}$. to a maximum of $204 \mathrm{mg} . / 100 \mathrm{ml}$. three days after admission. At this time endogenous creatinine clearance was grossly reduced at $19.7 \mathrm{ml} / \mathrm{min}$. Fifteen days after admission the blood urea had fallen to $75 \mathrm{mg}$. $/ 100 \mathrm{ml}$. and creatinine clearance had increased to $41 \mathrm{ml} . / \mathrm{min}$. Evidence of hepatic impairment was shown by the raised serum transaminase on admission. This increased to over 100 i.u. after 48 hours and then fell promptly to within normal limits.

\section{Case 3}

This man began to recover consciousness in the Accident Room. He was confused and remained amnesic for the events preceding his collapse. His speech was slurred and he was ataxic on walking. His expired air smelled strongly of solvent. His temperature was $98.6^{\circ} \mathrm{F}$. $\left(37^{\circ} \mathrm{C}\right.$.). The pulse was $88 / \mathrm{min}$. and regular and the blood pressure was $120 / 90$. Investigations on admission are shown in the Table.

Investigations on Admission in Cases 2 and 3

\begin{tabular}{|c|c|c|c|}
\hline & & Case 2 & Case 3 \\
\hline Chest $x$-ray film & . . & $\begin{array}{l}\text { Patchy diffuse opacity in } \\
\text { both lung fields }\end{array}$ & Normal \\
\hline Urine analysis & . & $\begin{array}{l}\text { Sugar, negative. Protein, } \\
\text { trace }\end{array}$ & $\begin{array}{l}\text { Sugar, negative. Protein, } \\
\text { negative }\end{array}$ \\
\hline $\begin{array}{l}\text { Haemoglobin } \\
\text { W.C.C. . . } \\
\text { Blood film }\end{array}$ & $\begin{array}{l}\cdots \\
\cdots \\
\cdots\end{array}$ & $\begin{array}{l}15.9 \mathrm{~g} . / 100 \mathrm{ml} \\
20,000 / \mathrm{cu} . \mathrm{mm} . \\
\text { Polymorphonuclear }\end{array}$ & $\begin{array}{l}15.6 \mathrm{~g} . / 100 \mathrm{ml} \\
14,700 / \mathrm{cu} . \mathrm{mm} \\
\text { Normal }\end{array}$ \\
\hline $\begin{array}{l}\text { Blood urea } \\
\text { Electrolytes (mEq/1.) }\end{array}$ & . & $\begin{array}{l}\text { leucocytosis } \\
59 \text { mg. } / 100 \mathrm{ml} \text {. } \\
\mathrm{Na}, 146 ; \mathrm{K}, 3.3 ; \mathrm{Cl}, 90 ; \\
\text { bicarbonate, } 26\end{array}$ & $\begin{array}{l}20 \mathrm{mg} .100 \mathrm{ml} . \\
\text { Na, } 145 ; \mathrm{K}, 3 \cdot 8 ; \mathrm{Cl}, 100 \\
\quad \text { bicarbonate, } 27\end{array}$ \\
\hline $\begin{array}{l}\text { Bilirubin } \\
\text { Flocculation tests } \\
\text { S.G.O.T. } \\
\text { Alkaline phosphatase } \\
\text { E.S.R. . . . . }\end{array}$ & & $\begin{array}{l}0.7 \mathrm{mg} . / 100 \mathrm{ml} . \\
\text { Normal } \\
64 \text { i.u. (normal } 4-20 \text { i.u.) } \\
32 \text { i.u. (normal } 20-85 \text { i.u.) } \\
5 \mathrm{~mm} \text {. in } 1 \text { hour }\end{array}$ & $\begin{array}{l}0.5 \mathrm{mg} . / 100 \mathrm{ml} . \\
\text { Normal } \\
36 \text { i.u. } \\
50 \text { i.u. } \\
10 \mathrm{~mm} . \text { in } 1 \text { hour }\end{array}$ \\
\hline
\end{tabular}

His recovery was slow but uneventful. He was fully conscious and alert within 24 hours of admission and the ataxia disappeared over 48 hours. No evidence of renal impairment was observed, but there was some indication of liver cell damage in that the serum transaminase, which was already raised on admission, rose to a maximum of 52 i.u. after 48 hours, falling thereafter to within normal limits.

\section{Investigation}

Solvent represented $34^{\prime \prime}$, of the total by weight of the paint and comprised a mixture of substances with xylene present in excess of $90 \%$. There were also traces of toluene.

About $1 \frac{1}{2}$ gallons (6.8 litres) of paint had been applied on three separate locations; this represented about one hour's work for three men. Two tins of cleaning fluid, each containing about half a gallon ( 2.3 litres), were also found in the space, and analysis showed this to be predominantly toluene.

Estimations of the probable xylene concentration in the space showed this to be in the region of 10,000 p.p.m. This figure was based on the quantity of paint which had been applied, the volume of the space, and assumed still air conditions. None of the men was wearing a respirator. Ventilation of the space was mini$\mathrm{mal}$ and consisted of a length of $3 \frac{1}{2}-\mathrm{in}$. $(8.9 \mathrm{~cm}$.) diameter flexible ducting attached to an extractor fan. This ducting was only long enough to reach just outside an access manhole and would have virtually no effect on air movement at the far end of the coffer dam where the men were working. Evaporation of the cleaning fluid might have been an additional factor, but neither of the rescued men had any recollection of the fluid being used.

One of the rescued men (Case 2) left the coffer dam at lunchtime and walked about 3 miles $(4.8 \mathrm{~km}$.) to his home. He returned at about 1.15 p.m., but does not remember anything else until he recovered consciousness in hospital. Patient 3 cannot remember anything after 10.30 a.m.

\section{Discussion}

The effect of xylene on the haemopoietic system is much less than that of benzene. Cases of poisoning were reported by Lob (1952), but in these the presence of benzene or toluene cannot be ruled out. Damage to the liver as a result of injection of xylene has been reported by Ghislandi and Fabiani (1957) and damage to the kidneys has been suggested by Joyner and Pegues (1961). The only fatal case of poisoning in which xylene might be incriminated was described by Koelsch (1946) (cited by Stocké, 1931) and was due to Intertol, which contained $35 \%$ of benzole and its homologues. Before incriminating xylene as the cause of unconsciousness and death in the cases reported above it is necessary to exclude two other possibilities. Firstly, it is not expected that there would have been sufficient vaporization from the toluene cleaning fluid to have an effect on the men. There is also no evidence that the concentration of oxygen in the air in the space would be reduced appreciably. Diffusion through the manholes would be ample to maintain a normal oxygen percentage.

We have come to the conclusion, therefore, that this paper reports the first fatal case of xylene poisoning by inhalation of fumes and also records prolonged unconsciousness in two other patients who subsequently recovered.

There is no record of xylene having been used as a general anaesthetic, but it is interesting that the substance was able to maintain unconsciousness in one patient for 18 hours and in the other for about 15 hours, with surprisingly little effect.

\section{RERERENCES}

Browning, E. (1965). Toxicity and Metabolism of Industrial Solvents, p. 77. Amsterdam, Elsevier.

Ghislandi, E., and Fabiani, A. (1957). La Medicina del Lavoro, 48, 577. Johnstone, R. T., and Miller, S. E. (1960). Occupational Diseases and Industrial Medicine. Philadelphia Saunders.

Joyner, R. E., and Pegues, W. L. (1961). Journal of Occupational Medicine, 3, 211 .

Koelsch, F. (1946). Lehrbuch der Arbeitshygiene, vol. 1, p. 286. Stuttgart, Enke.

Lob, M. (1952). Schweizerische medizinische Wochenschrift, 43, 1125.

Stocké, A. (1931). Archiv für Gewerbepathologie und Gewerbehygiene, 2, 99. 